Published by Al-Nahrain College of Medicine P-ISSN 1681-6579

E-ISSN 2224-4719

Email: iraqijms@colmed-alnahrain.edu.iq

http://www.colmed-alnahrain.edu.iq

http://www.iraqijms.net

Iraqi JMS 2018; Vol. 16(2)

\title{
Identification of Common Aerobic Bacterial Isolates among Conjunctivitis in Sulaymaniyah Province / Iraq
}

\author{
khanda A. Anoar ${ }^{1}$ PhD, Tara M. Hassan ${ }^{2}$ SMSB (Ophthalmoloty), Bayan T. Majid ${ }^{1}$ MsC
}

${ }^{1}$ Dept. of Microbiology, ${ }^{2}$ Dept. of Surgery, College of Medicine, University of Sulaymaniyah, Iraq,

\begin{abstract}
Background Bacterial conjunctivitis is a microbial infection of the mucous membrane of the conjunctiva of eye that occurs both in adults and children. It is produced by an array of microorganisms that is frequently isolated from the conjunctiva of healthy subjects. The normal conjunctival flora represents both bacterial colonization and transient or recurring bacterial contamination. Coagulase-negative Staphylococci and Corynebacteria are frequently present on the healthy conjunctiva, but more traditionally pathogenic organisms, such as coagulase-positive Staphylococci, Streptococci, Haemophilus species, Moraxellae and Gram negative coliform rods occasionally isolated from normal, non-inflamed eyes.

Objective To determine etiological agents of aerobic bacterial conjunctivitis and the prevalence of each bacteria and its relation with the conjunctival discharge.

Methods This study conducted on 100 conjunctival samples from patients with conjunctivitis, and 50 samples from healthy normal persons. All samples were cultured on enriched media like blood agar and chocolate agar, anti-microbial susceptibility of all 100 samples from patients were analyzed.

Results The prevalence of aerobic bacterial conjunctivitis is 53 \%with predominance age of 1-10 years. The most common bacterial isolates were Staphylococcus epidermidis followed by Streptococcus pneumonia. Most of the isolates were sensitive to cefotaxime and ofloxacillin, while different result was detected regarding resistance of each isolated bacteria.

Conclusion Aerobic bacterial isolates can be detected both in conjunctivitis and normal healthy individual with similarity regarding the type of bacteria that affect all age group.

Keywords Conjunctivitis, commensal flora, conjunctival discharge

Citation

Anoar KA, HassanTM, Majid BT. Identification of common aerobic bacterial isolates among conjunctivitis in Sulaymaniyah Province / Iraq. Iraqi JMS. 2018; 16(2): 223-229. doi: 10.22578/IJMS.16.2.15
\end{abstract}

List of abbreviations: $A P I=$ Analytic profile index, $\mathrm{CLNI}=$ Clinical and Laboratory Standard Institute of antimicrobial susceptibility testing

\section{Introduction}

$\mathrm{C}$ onjunctivitis is a nonspecific term used to describe inflammation of ocular surface from either infectious or none infectious causes (1). Viruses and bacteria are the most common infectious causes, noninfectious conjunctivitis includes allergic, toxic, as well as inflammation secondary to immune mediated diseases and neoplastic processes (2). The acute infective causes (viruses and bacteria) are the most frequently encountered ocular disorders in primary care, making up to $1-2 \%$ of all family medicine consultations ${ }^{(3)}$.

The conjunctival flora is found on the ocular surface of healthy individuals and under normal conditions comprises noninfectious 
microorganisms and these microorganisms have an important role in the maintenance of normal conjunctival functions and the prevention of ocular infections ${ }^{(4)}$.

Infection can involve the eye itself and or the tissue surrounding the eye, may be unilateral or bilateral (one or both eyes), or it can spread from one eye to infect other one ${ }^{(5)}$.

The most prominent symptoms of acute infective conjunctivitis are mild pruritus, foreign body sensation, and intolerance to light and redness while most prominent signs include crusted eyelids that are often matted together, especially after sleep, watery or purulent discharge from one or both eyes ${ }^{(6)}$.

The prevalence of conjunctivitis varies according to the underlying cause, which may be influenced by the patient's age, as well as the season of the year. Viral conjunctivitis is the most common cause of infectious conjunctivitis both overall and in the adult population and is more prevalent in summer (7), while bacterial conjunctivitis is the second most common causes and is responsible for the majority of cases (50-75\%) and observed more frequently from December through April (8). While allergic conjunctivitis is the most frequent cause, affecting $15-40 \%$ of the population, and is observed more frequently in spring and summer (9).

The most common etiologic agents of conjunctivitis are Gram-positive organisms such as Staphylococcus species, Streptococcus pneumoniae, Streptococcus viridians (10). Infections with Streptococcus pneumoniae and Haemophilus Influenzae are more common in children, while Staphylococcus aureus most frequently affects adults (11), while other organisms such as Bacteroides, Corynebacterium diphtheriae and Moraxella catarrhalis account for the lesser percentage of causes ${ }^{(12)}$. Gram negative organisms, such as Escherichia coli, Klebsiella pneumoniae, Serratia marcescens, Proteus, Enterobacter, and Pseudomonas species have been implicated also as lesser causes of conjunctivitis ${ }^{(13)}$. Chlamydia trachomatis and
Neisseria gonorrhea are the two well described agents associated with ophthalmia neonatorum, and are known to be associated with systemic complication ${ }^{(14)}$. The majority of infectious neonatal conjunctivitis cases are due to bacterial etiology, though most of these cases are benign, some of them may progress to systemic complications or visual loss (15).

The aim of this study was to identify etiological agents of aerobic bacterial conjunctivitis in all age group and finding any relation with conjunctival discharge.

\section{Methods}

This study was conducted in Outpatient Ophthalmology Clinic of Shahid Aso Hospital in Sulaymaniyah, Iraq from a period of March October 2017, after obtaining informed consent from all the participants: swabs from conjunctiva were collected from two groups; 100 from patients suspected to had acute conjunctivitis and 50 samples from healthy control persons. Age occupation, sex and eye discharge were asked from both groups and recorded.

All the samples were collected using a cotton tipped swab applicator pre-moistened with sterile saline. The swab was placed in the transport medium and transferred to the Microbiology Lab in College of Medicine, University of Sulaymaniyah. All the samples were processed through culturing on different culture media (blood, MacConkey agar, chocolate agar) under aerobic condition and using candle jar for incubation of streaked chocolate agar for 24-48 hours. After incubation final diagnosis were done by doing Gram stain on positive culture and using several biochemical tests such as coagulase, catalase, oxidase mannitol fermentation test and Analytic Profile Index (API) system for final diagnosis of bacterial species ${ }^{(16)}$.

Antibiotic susceptibility was examined for all bacterial species according to Clinical and Laboratory Standard Institute of antimicrobial susceptibility testing (CLNI) 2015 by using 10 selected antimicrobial agents ${ }^{(17)}$. 
Results

This study included 100 patients with clinical history of conjunctivitis and 50 healthy control group. Female 45, male 55 among conjunctivitis and 31 female , 19 male in control group. Different age group were participated in the study from less than 1 year to 80 years with mean age 40.5 , with predominance of $1-10$ years as the most affected age group by infection. Table 1 demonstrates age and sex of participant among conjunctivitis group.

Table 1. Age and gender of patients with conjunctivitis

\begin{tabular}{cccc}
\hline Age group & Male & Female & Total \\
\hline$<1$ & 0 & 3 & 3 \\
$1-10$ & 22 & 14 & 36 \\
$\mathbf{1 1 - 2 0}$ & 4 & 3 & 7 \\
$\mathbf{2 1 - 3 0}$ & 4 & 3 & 7 \\
$\mathbf{3 1 - 4 0}$ & 4 & 8 & 12 \\
$\mathbf{4 1 - 5 0}$ & 11 & 6 & 17 \\
$\mathbf{5 1 - 6 0}$ & 4 & 2 & 6 \\
$\mathbf{6 1 - 7 0}$ & 3 & 3 & 6 \\
$\mathbf{7 1 - 8 0}$ & 3 & 3 & 6 \\
\hline Total & 55 & 45 & 100 \\
\hline
\end{tabular}

The prevalence of aerobic bacterial conjunctivitis is $53 \%$ with predominance of Staphylococcus species $34 \%$ followed by Streptococcus pneumonia $13 \%$ and $2 \%$ for each of Diphtherioid, Neisseria gonorrhea and Gram- negative bacteria, while bacterial isolates among control group account for 52\% with predominance of Staphylococcus epidermidis (Figure 1).

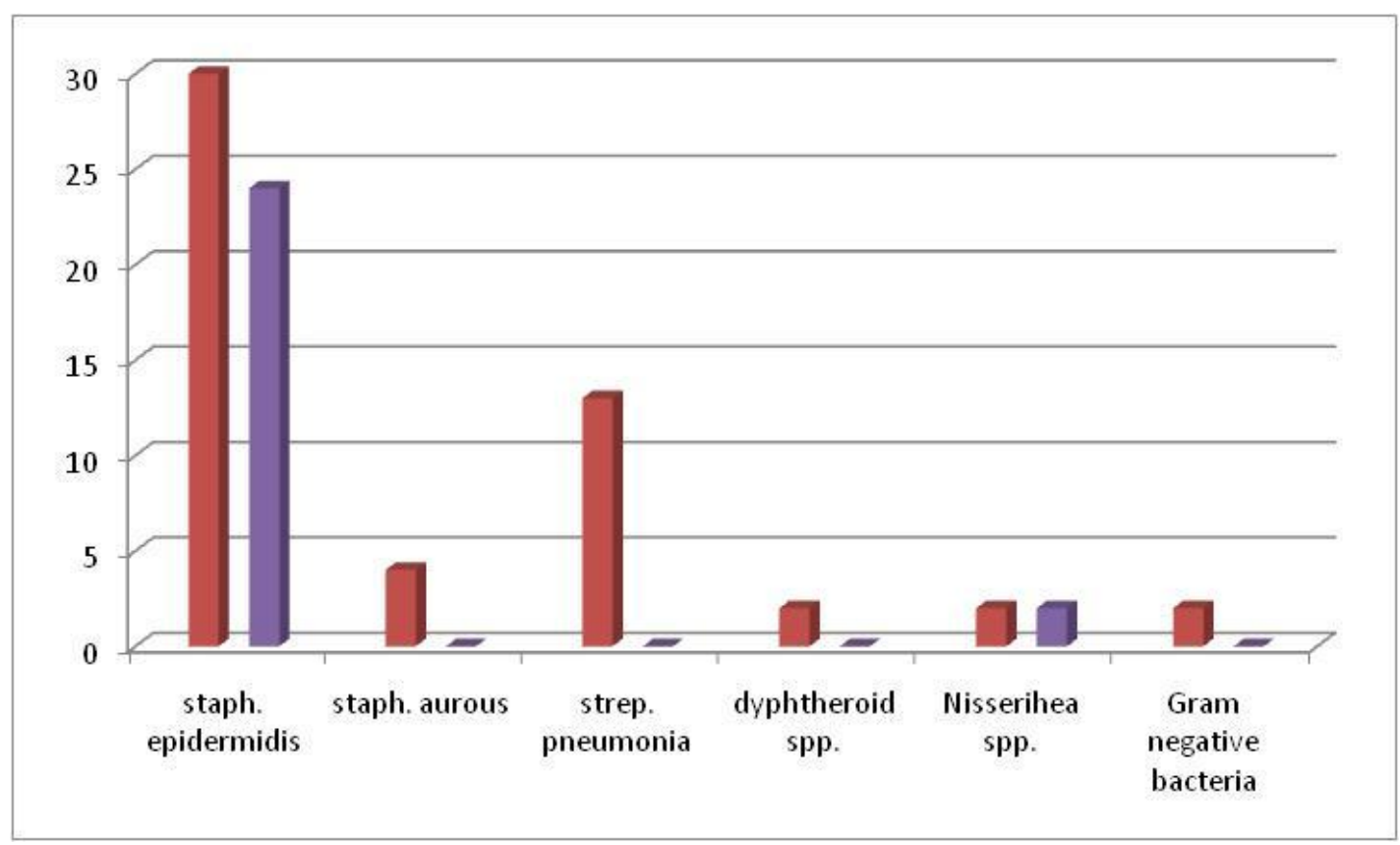

Figure 1. Distribution of aerobic microorganisms among conjunctivitis and control group 
One of the symptoms of conjunctivitis is red eye which was observed among all patients with conjunctivitis followed by presence of eye discharge. Table 2 illustrates the presence of eye discharge among positive and negative culture $(p>0.05)$.

Table 2. Distribution of eye discharge in relation of culture result among conjunctivitis

\begin{tabular}{cccc}
\hline \multirow{2}{*}{ Culture results } & \multicolumn{2}{c}{ Eye Discharge } & Total \\
\hline Positive culture & Positive & Negative & 53 \\
Negative culture & 41 & 12 & 47 \\
\hline Total & 37 & 10 & 100 \\
\hline $\mathrm{X} 2=0.270, \mathrm{DF}=1, \mathrm{P}=0.869$ & 78 & 22 &
\end{tabular}

The type of discharge also analyzed in this study and it was differ according to the isolates and each type of bacteria producing different discharge but purulent discharge is the commonest one (Table 3 ) although statistically this variation is not significant $p$ value $>0.05$.

Table 3. Distribution of eye discharge in relation of culture result among conjunctivitis

\begin{tabular}{cccccc}
\hline \multirow{2}{*}{ Microorganisms isolated } & \multicolumn{4}{c}{ Type of discharge } & \multicolumn{2}{c}{ Total } \\
& Mucoid & Watery & Purulent & None & \\
\hline Staphylococcus species & 5 & 8 & 9 & 12 & 34 \\
Streptococcus species & 2 & 4 & 7 & 0 & 13 \\
Diphtheria species & 0 & 1 & 1 & 0 & 2 \\
Neisseria species & 0 & 0 & 2 & 0 & 2 \\
Gram negative & 1 & 1 & 0 & 0 & 2 \\
\hline Total & 8 & 14 & 19 & 12 & 53 \\
\hline
\end{tabular}

$P$ value $=0.838$

Antimicrobial susceptibility was done for all isolated bacteria from conjunctivitis patients and the result was different according to each species of bacteria as shown in table 4.

The most resistant drugs against Staphylococci is tetracycline (76.66\%) followed by erythromycin (70\%), trimethoprim (56.66\%), while gentamycin was the most resistant drug against Streptococcus pneumonia (69.23\%).

The best drug to treat conjunctivitis is cefotaxime which has $76.66 \%$ efficiency against Staphylococcus epidermidis and $100 \%$ against Staphylococcus aureus, Streptococcus pneumoniae and Diphtheria species. On the other hand, sensitivity to ofloxacillin was detected in $56.66 \%$ of Streptococcus epidermidis, $75 \%$ of Streptococcus pneumoniae and $84.61 \%$ of Staphylococcus aureus.

\section{Discussion}

Bacterial conjunctivitis can be contracted directly from infected individuals or can result from abnormal proliferation of the native conjunctival flora, contaminated fingers, ocular genital spread and contaminated fomites are common routes of transmission (17).

The prevalence of aerobic bacterial conjunctivitis is $53 \%$ with predominance of Gram positive bacteria such as Staphylococcus epidermidis as the major pathogens followed by Streptococcus pneumonia, which is compatible with other studies ${ }^{(18-21)}$. In spite of this result, there is study in which Gramnegative bacteria such as Pseudomonas aeruginosa is the predominance microorganisms followed by Staphylococcus aurous ${ }^{(5)}$.

Negative culture was detected among $47 \%$ apart from symptoms and signs of conjunctivitis, in which other etiology may the 
causes such as viral, allergic, anaerobic bacteria and Chlamydia that they require special technique for their isolation and they are not included in this study.

Table 4. Antimicrobial susceptibility results for all bacterial isolates from conjunctivitis

\begin{tabular}{|c|c|c|c|c|c|c|c|c|c|c|c|}
\hline \multirow{2}{*}{$\begin{array}{c}\text { isolated } \\
\text { microorganisms }\end{array}$} & \multicolumn{11}{|c|}{ antimicrobial antibiotics } \\
\hline & No\% & $\mathrm{C}$ & $\mathrm{T}:$ & E: & $\mathrm{CN}:$ & CIP: & OFX & CTX & MEM & TM & $\mathrm{CRO}$ \\
\hline \multirow{3}{*}{$\begin{array}{l}\text { staphylococcus } \\
\text { epidermidis } \\
\text { (30) }\end{array}$} & $\mathrm{R}$ & $\begin{array}{c}10 \\
(33.33) \\
\end{array}$ & $\begin{array}{c}23 \\
(76.66) \\
\end{array}$ & $\begin{array}{c}21 \\
(70) \\
\end{array}$ & $\begin{array}{c}12 \\
(40) \\
\end{array}$ & $\begin{array}{c}13 \\
(43.33) \\
\end{array}$ & $\begin{array}{c}13 \\
(43.33) \\
\end{array}$ & $\begin{array}{c}7 \\
(23.33) \\
\end{array}$ & $\begin{array}{c}11 \\
(36.66) \\
\end{array}$ & $\begin{array}{c}17 \\
(56.66) \\
\end{array}$ & $\begin{array}{c}11 \\
(36.56) \\
\end{array}$ \\
\hline & $S$ & $\begin{array}{c}20 \\
(66.66) \\
\end{array}$ & $\begin{array}{c}7 \\
(23.33) \\
\end{array}$ & $\begin{array}{c}8 \\
(26.66) \\
\end{array}$ & $\begin{array}{c}17 \\
(56.66) \\
\end{array}$ & $\begin{array}{c}13 \\
(43.33) \\
\end{array}$ & $\begin{array}{c}17 \\
(56.66) \\
\end{array}$ & $\begin{array}{c}23 \\
(76.66) \\
\end{array}$ & $\begin{array}{c}19 \\
(63.33) \\
\end{array}$ & $\begin{array}{c}13 \\
(43.33) \\
\end{array}$ & $\begin{array}{c}18 \\
(60) \\
\end{array}$ \\
\hline & I & 0 & 0 & $\begin{array}{c}1 \\
(3.33) \\
\end{array}$ & $\begin{array}{c}1 \\
(3.33) \\
\end{array}$ & $\begin{array}{c}4 \\
(13.33) \\
\end{array}$ & 0 & 0 & 0 & 0 & $\begin{array}{c}1 \\
(3.33) \\
\end{array}$ \\
\hline \multirow{3}{*}{$\begin{array}{l}\text { Staphylocous } \\
\text { aurous (4) }\end{array}$} & $\mathrm{R}$ & 0 & $\begin{array}{c}1 \\
(25) \\
\end{array}$ & $\begin{array}{c}2 \\
(50) \\
\end{array}$ & $\begin{array}{c}2 \\
(50) \\
\end{array}$ & $\begin{array}{c}2 \\
(50) \\
\end{array}$ & $\begin{array}{c}1 \\
(25) \\
\end{array}$ & 0 & $\begin{array}{c}1 \\
(25) \\
\end{array}$ & 0 & 0 \\
\hline & $\mathrm{S}$ & $\begin{array}{c}4 \\
(100) \\
\end{array}$ & $\begin{array}{c}3 \\
(75) \\
\end{array}$ & $\begin{array}{c}2 \\
(50) \\
\end{array}$ & $\begin{array}{c}2 \\
(50) \\
\end{array}$ & $\begin{array}{c}2 \\
(50) \\
\end{array}$ & $\begin{array}{c}3 \\
(75) \\
\end{array}$ & $\begin{array}{c}4 \\
(100) \\
\end{array}$ & $\begin{array}{c}3 \\
(75) \\
\end{array}$ & $\begin{array}{c}4 \\
(100) \\
\end{array}$ & $\begin{array}{c}4 \\
(100) \\
\end{array}$ \\
\hline & I & 0 & 0 & 0 & 0 & 0 & 0 & 0 & 0 & 0 & 0 \\
\hline \multirow{3}{*}{$\begin{array}{l}\text { streptococcus } \\
\text { pneumonia } \\
\text { (13) }\end{array}$} & $\mathrm{R}$ & $\begin{array}{c}2 \\
(15.38) \\
\end{array}$ & $\begin{array}{c}6 \\
(46.15) \\
\end{array}$ & $\begin{array}{c}7 \\
(53.84) \\
\end{array}$ & $\begin{array}{c}9 \\
(69.23) \\
\end{array}$ & $\begin{array}{c}2 \\
(15.38) \\
\end{array}$ & 0 & 0 & $\begin{array}{c}3 \\
(23.07) \\
\end{array}$ & $\begin{array}{c}6 \\
(46.15) \\
\end{array}$ & $\begin{array}{c}1 \\
(7.69) \\
\end{array}$ \\
\hline & $\mathrm{S}$ & \begin{tabular}{|c|}
11 \\
$(84.61)$ \\
\end{tabular} & $\begin{array}{c}7 \\
(53.84) \\
\end{array}$ & $\begin{array}{c}6 \\
(46.15) \\
\end{array}$ & $\begin{array}{c}4 \\
(30.76) \\
\end{array}$ & $\begin{array}{c}11 \\
(84.61) \\
\end{array}$ & $\begin{array}{c}11 \\
(84.61) \\
\end{array}$ & $\begin{array}{c}13 \\
(100) \\
\end{array}$ & $\begin{array}{c}10 \\
(76.92) \\
\end{array}$ & $\begin{array}{c}7 \\
(53.84) \\
\end{array}$ & $\begin{array}{c}12 \\
(92.3) \\
\end{array}$ \\
\hline & I & 0 & 0 & 0 & 0 & & $\begin{array}{c}2 \\
(15.38)) \\
\end{array}$ & 0 & 0 & 0 & \\
\hline \multirow{3}{*}{$\begin{array}{l}\text { Diphtheriod } \\
\text { Species (2) }\end{array}$} & $\mathrm{R}$ & 0 & 0 & 0 & 0 & 1 & 0 & 0 & 0 & $\begin{array}{c}1 \\
(50) \\
\end{array}$ & 0 \\
\hline & $\mathrm{S}$ & $\begin{array}{c}2 \\
(100) \\
\end{array}$ & $\begin{array}{c}2 \\
(100) \\
\end{array}$ & $\begin{array}{c}2 \\
(100) \\
\end{array}$ & $\begin{array}{c}2 \\
(100) \\
\end{array}$ & $\begin{array}{c}1 \\
(50) \\
\end{array}$ & $\begin{array}{c}2 \\
(100) \\
\end{array}$ & $\begin{array}{c}2 \\
(100) \\
\end{array}$ & $\begin{array}{c}2 \\
(100) \\
\end{array}$ & $\begin{array}{c}1 \\
(50) \\
\end{array}$ & $\begin{array}{c}2 \\
(100) \\
\end{array}$ \\
\hline & I & 0 & 0 & 0 & 0 & 0 & 0 & 0 & 0 & 0 & 0 \\
\hline \multirow{3}{*}{$\begin{array}{c}\text { Gram negative } \\
\text { bacteria } \\
\text { (2) }\end{array}$} & $\mathrm{R}$ & 0 & 0 & 0 & 0 & $\begin{array}{c}2 \\
(100) \\
\end{array}$ & $\begin{array}{c}1 \\
(50) \\
\end{array}$ & 0 & $\begin{array}{c}2 \\
(100) \\
\end{array}$ & 0 & 0 \\
\hline & $\mathrm{S}$ & $\begin{array}{c}2 \\
(100) \\
\end{array}$ & $\begin{array}{c}2 \\
(100) \\
\end{array}$ & $\begin{array}{c}2 \\
(100) \\
\end{array}$ & $\begin{array}{c}2 \\
(100) \\
\end{array}$ & 0 & $\begin{array}{c}1 \\
(50) \\
\end{array}$ & $\begin{array}{c}2 \\
(100) \\
\end{array}$ & 0 & $\begin{array}{c}2 \\
(100) \\
\end{array}$ & $\begin{array}{c}2 \\
(100) \\
\end{array}$ \\
\hline & I & 0 & 0 & 0 & 0 & 0 & 0 & 0 & 0 & 0 & 0 \\
\hline \multirow{3}{*}{$\begin{array}{l}\text { Niserihea species } \\
\text { (2) }\end{array}$} & $\mathrm{R}$ & 0 & $\begin{array}{c}1 \\
(50) \\
\end{array}$ & $\begin{array}{c}2 \\
(100) \\
\end{array}$ & $\begin{array}{c}1 \\
(50) \\
\end{array}$ & 0 & 0 & $\begin{array}{c}1 \\
(50)\end{array}$ & $\begin{array}{c}1 \\
(50) \\
\end{array}$ & $\begin{array}{c}2 \\
(100) \\
\end{array}$ & $\begin{array}{c}1 \\
(50)\end{array}$ \\
\hline & $S$ & $\begin{array}{c}2 \\
(100) \\
\end{array}$ & $\begin{array}{c}1 \\
(50)\end{array}$ & 0 & $\begin{array}{c}1 \\
(50)\end{array}$ & $\begin{array}{c}2 \\
(100) \\
\end{array}$ & $\begin{array}{c}2 \\
(100) \\
\end{array}$ & $\begin{array}{c}1 \\
(50) \\
\end{array}$ & $\begin{array}{c}1 \\
(50) \\
\end{array}$ & 0 & $\begin{array}{c}1 \\
(50) \\
\end{array}$ \\
\hline & I & 0 & 0 & 0 & 0 & 0 & 0 & 0 & 0 & 0 & 0 \\
\hline
\end{tabular}

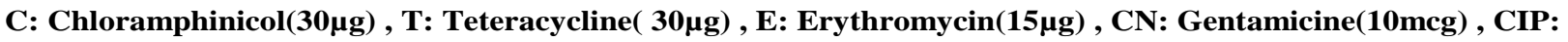
ciprofloxacine(10mcg), OFX: Ofloxacine(5mcg), CTX: Cefotaxime(30mcg), MEM: Meropenem(10mcg), TM: Trimethoprime(5mcg), CRO: Ceftriaxone(30 $\mathrm{\mu g})$

Bacteria may frequently be isolated from the conjunctiva of healthy subjects and is frequently comprised of same microorganisms as the skin flora and upper respiratory tract ${ }^{(22)}$. The present study revealed the major causative pathogens both in conjunctivitis and healthy group are the same in spite of that conjunctival flora forms a defensive barrier against infection, it also includes major pathogens of ocular infections ${ }^{(23)}$.
The most affected age group is between 1-10 years and 40-50 years of age, which is compatible with study done ${ }^{(24,25)}$ as children more prone to infection due improper sanitary condition by their parents and adult above 40 are prone to infection due to contact with dirty subject in their work.

One of the hallmark of conjunctivitis is the presence of eye discharge and it was present in all positive culture and in $37 \%$ of negative culture, although different eye discharge was 
observed but purulent discharge is the commonest specifically among Streptococcus pneumonia and both cases of Neisseria as other study done (26).

Although $60 \%$ of cases of suspected or cultureproven acute bacterial conjunctivitis are selflimiting within 1 to 2 weeks of presentation (7) the antimicrobial susceptibility profile done in this study and revealed that cefotaxime and ofloxacillin is the best drug to treat conjunctivitis as observed also by others (22) followed by gentamycin, ciprofloxacillin and meropenem but there are others research in which gentamycin is the more sensitive drug with ciprofloxacillin (27-29) and other conclude macrolide antibiotic eye drop containing 1\% azithromycin that was approved in the USA in 2007 is the drug of choice (30). The resistant pattern also differs according to bacterial species, in general tetracycline and erythromycin were the most drugs that bacteria exhibited resistance against, while Staphylococcus epidermidis showed resistance to chloramphenicol which gave better result against Staphylococcus aureus and Streptococcus pneumonia than tetracycline (31). However, there is some researches, in which Streptococcus pneumonia is highly resistant type of bacteria $(32,33)$.

This study concluded that bacterial conjunctivitis is common in all age group with predominance of Gram positive microorganisms similar to what was isolated in normal healthy subject. Cefotaxim and ofloxacillin regarded as the best drug of choice for treatment of conjunctivitis.

\section{Acknowledgments}

The authors would like to thanks Ophthalmology Unit in Shahid ASO Hospital in Sulaymaniyah for their cooperation regarding taking of samples from patients and great thanks to all the patients and control group that participated in the study for their cooperation and allowance for taking samples.

\section{Authors contribution}

Dr Hassan: taking patients history and examination, all the samples were analyzed and processed by Dr Anoar and Majid, and all of three authors participated in writing of paper.

\section{Conflict of interest}

no conflict of interest regarding all three authors that participated in this study to any other company or any organized sit with best regards.

\section{Funding}

The whole fund of the research was paid by all three authors themselves regarding all material that needed for bacteriological process.

\section{References}

1. Tu EY. Conjunctivitis. In: Schlossberg D. Clinical infectious disease. 2nd ed. Cambridge University Press; $2005 . \quad$ p. 81-7. doi: https://doi.org/10.1017/CBO9781139855952.015.

2. American Academy of Ophthalmology/ External Disease PPP Panel, Hoskins Center for Quality Eye Care. Conjunctivitis PPP - 2013. URL: https://www.aao.org/preferred-practicepattern/conjunctivitis.

3. Visscher KL, Hutnik CML, Thomas M. Evidence-based treatment of acute infective conjunctivitis - Breaking the cycle of antibiotic prescribing. Can Fam Physician. 2009; 55(11): 1071-5.

4. Adam M, Balc M, Bayhan HA, et al. Conjunctival flora in diabetic and nondiabetic individuals. Turk J Ophthalmol. 2015; 45(5): 193-6. doi: 10.4274/tjo.33230.

5. Alash SAA. Study the prevalence of bacterial conjunctivitis in Iraq. Iraqi J Sci. 2015; 56(4): 3371-5.

6. Rose P. Management strategies for acute infective conjunctivitis in primary care: a systematic review. Expert Opin Pharmacother; 2007. 8(12): 1903-21. doi: 10.1517/14656566.8.12.1903.

7. Azari AA, Barney NP. Conjunctivitis. A systematic review of diagnosis and treatment. JAMA; 2013; 310(16): 1721-9. doi: 10.1001/jama.2013.280318.

8. Fischbach F, Dunning MB. A manual of laboratory diagnostic tests/ microbiological study. $9^{\text {th }}$ ed. Wolters Kluwer; 2015. p. 526.

9. Høvding G. Acute bacterial conjunctivitis. Acta Ophthalmol Scand; $2008 . \quad 86(1)$ : 5-17. DOI:10.1111/j.1600-0420.2007.01006.x

10. Hutnik CML, Mohammad-Shahi MH. Bacterial conjunctivitis. Clin Ophthalmol. 2010; 4: 1451-7. doi: 10.2147/OPTH.S10162.

11. Al-Dorri AZR, Al-jebouri WMR. Microbiological study of patients with conjunctivitis in Tikrit Teaching Hospital. Tikrit Med J. 2005; 11(2): 28-34.

12. Silverstein BE, Morris TW, Gearinger LS, et al. Besifloxacin ophthalmic suspension $0.6 \%$ in the treatment of bacterial conjunctivitis patients with Pseudomonas aeruginosa infections. Clin 
Ophthalmol. 2012; 6: 1987-96. doi: 10.2147/OPTH.S35715.

13. Afjeiee SA, Tabatabaei SR, Fallah $F$, et al. A microbiological study of neonatal conjunctivitis in two hospitals in Tehran, Iran. BMC Infect Dis. 2012; 12(Suppl 1): P48. doi: 10.1186/1471-2334-12-S1P48.

14. Chikviladze D, Nikuradze N, Gachechiladze Kh, et al. [Microbial structure of acute bacterial conjunctivitis]. Georgian Med News; 2013. 216: 12-5.

15. Khoshdel A, Taheri $S$, Khadivi $R$, et al. Incidence and bacteriological profile of neonatal conjunctivitis in Hajar Hospital, Shahrekord, Iran. Iranian J Pathol; 2012. 7(2), 86-9.

16. Mahon CR, Lehman DC, Manuselis G. Text book of diagnostic microbiology. $3^{\text {rd }}$ ed. Saunders Elsevier; 2007. p. 152.

17. Clinical and Laboratory Standards Institute. M100S25 Performance standards for antimicrobial susceptibility testing; Twenty fifth informational supplement. 2015. M02-V. 35, No. 3.

18. Al-Hadithi HT, Al-Mearaj KI, Al-Hammadi MA. Incidence of Methicilin resistant Staphylococci in bacterial conjunctivitis. Bas J Surg; 2006. 12(1): 98-9.

19. Samadi R, Eslami G, Taheri S, et al. Survey the Prevalence Bacterial Agents in Patients with Conjunctivitis Infection in Farabi Hospital Tehran. Res Med; 2013. 36(4); 189-92.

20. Sharma PD, Sharma N, Gupta RK, et al. Aerobic bacterial flora of the normal conjunctiva at high altitude area of Shimla Hills in India: a hospital based study. Int J Ophthalmol; 2013. 6(5): 723-6. doi: 10.3980/j.issn.2222-3959.2013.05.32.

21. Eshraghi B, Alemzadeh MA, Abeddinifar $Z$. Conjunctival bacterial flora in fellow eyes of patients with unilateral nasolacrimal duct obstruction and its changes after successful dacryocystorhinostomy surgery. J Curr Ophthalmol. 2017; 29(1): 59-62. doi: 10.1016/j.joco.2016.11.001.

22. Ramesh $S$, Ramakrishnan $R$, Bharathi $M J$, et al. Prevalence of bacterial pathogens causing ocular infections in South India. Indian J Pathol Microbiol. 2010; 53(2): 281-6. doi: 10.4103/0377-4929.64336.

23. Manav G, Bilgin L, Gezer A, ve ark.: Normal populasyonda konjonktival flora. T Oft Gaz. 1992; 12: 121-4.

24. Michael A, Bazira J. The etiology and antibiogram of bacterial causes of conjunctivitis among patients attending the eye clinic at Rugarama Hospital in
South Western Uganda. Ophthalmol Res: Int J. 2014. 2(6): 378-83.

25. Liang $Q$, Lu $X$, Wang $M$, et al. Ratio of infectious conjunctivitis among children in rural areas of Qinghai province. Sci China Life Sci. 2016; 59(6): 54854. doi: 10.1007/s11427-016-5058-x.

26. Khosravi AD, Mehdinejad $M$, Heidari $M$. Bacteriological findings in patients with ocular infection and antibiotic susceptibility pattern of isolated pathogens. Singapore Med J. 2007; 48(8): 741-3.

27. Wang N, Yang $Q$, Tan $Y$, et al. Bacterial spectrum and antibiotic resistance patterns of ocular infection: differences between external and intraocular diseases. J Ophthalmol; 2015. Article ID 813979, 7 pages. doi: http://dx.doi.org/10.1155/2015/813979.

28. Ahmed OB, Hamdan EM. Profile of bacterial conjunctivitis in Sudan. Sch J App Med Sci. 2016. 4(4B): 1217-21.

29. Ipe A, Navaneetha N, Skariah R. Profile of patients with ocular infections attending the out-patient department of a tertiary care centre in south India Int J Res Med Sci. 2016. 4(7): 3027-31. doi: http://dx.doi.org/10.18203/23206012.ijrms20161998.

30. Wickström K. Acute bacterial conjunctivitis - benefits versus risks with antibiotic treatment. Acta Ophthalmol. 2008; 86(1): 2-4. doi: 10.1111/j.16000420.2007.01110.x.

31. Crum NF, Barrozo CP, Chapman FA, et al. An outbreak of conjunctivitis due to a novel unencapsulated Streptococcus pneumoniae among military trainees. Clin Infect Dis. 2004; 39(8): 1148-54. doi: 10.1086/424522.

32. Karpecki $P$, Paterno MR, Comstock TL. Limitations of current antibiotic treatment of bacterial conjunctivitis. Optom Vis Sci. 2010. 87(11): 908-19. doi: 10.1097/OPX.0b013e3181f6fbb3.

33. Bertino JS Jr. Impact of antibiotic resistance in the managementof ocular infections: the role of current and future antibiotics. Clin Ophthalmol. 2009; 3: 50721.

\section{Correspondence to dr khanda A. Anoar \\ E-mail: khanda.anwar@univsul.edu.iq Received Oct. 18 2017 Accepted Feb. 25 2018}

